UNIVERSIDAD
AUTÓNOMA
METROPOLITANA
Unidad Iztapalapa

\title{
Rainbow trout (Oncorhynchus mykiss) growth and digestive enzymes activity fed with autochthonous probiotics
}

\section{Crecimiento y actividad de las enzimas digestivas de la trucha arcoiris (Oncorhynchus mykiss) alimentadas con probióticos \\ autóctonos}

José Alberto Ramírez-Torrez¹, María del Carmen Monroy-Dosta², Luis Héctor Hernández Hernández ${ }^{*}$, Jaime Bustos-Martínez ${ }^{4}$, Aida Hamdan-Partida ${ }^{4}$, Jorge Castro-Mejía ${ }^{5}$ and Dafne Itzel Orozco-Rojas' .

Alumno del Doctorado en Ciencias Biológicas y de la Salud, Universidad Autónoma Metropolitana-Xochimilco

2 Laboratorio de Análisis Químico de Alimento Vivo - Universidad Autónoma Metropolitana-Xochimilco

${ }^{3}$ Laboratorio de Producción Acuícola - Facultad de Estudios Superiores Iztacala, Universidad Nacional Autónoma de México

${ }^{4}$ Laboratorio de Microbiología y Biología Molecular - Universidad Autónoma Metropolitana-Xochimilco

${ }^{5}$ Laboratorio de Alimento Vivo - Universidad Autónoma Metropolitana-Xochimilco

Universidad Autónoma Metropolitana-Xochimilco. Calzada del Hueso 1100, Villa Quietud, Delegación Coyoacán, C.P. 04960 Ciudad de México, México

Facultad de Estudios Superiores Iztacala Avenida de los Barrios 1, Los Reyes Iztacala, 54090, Tlalnepantla, Estado de México México

*Corresponding author:

Luis Héctor Hernández Hernández: e-mail: luish3@yahoo.com

To quote as:

Ramírez-Torrez J. A., M. del C. MonroyDosta, L. H. Hernández Hernández, J Bustos-Martínez, A. Hamdan-Partida, J. Castro-Mejía, D. I. and Orozco-Rojas 2019. Growth and digestive enzymes activity of rainbow trout (Oncorhynchus mykiss) fed with autochthonous probiotics Hidrobiológica 29 (2): 73-81.

DOl: 10.24275/uam/izt/dcbs/hidro/2019v29n2/Ramirez

\begin{abstract}
Background: Probiotics in aquaculture are becoming important to improve the welfare of fishes because of some benefits to their physiological processes and, consequently, to their growth. Goals: To assess the effects of two autochthonous bacterial strains with probiotic features on the Rainbow trout growth and its digestive enzyme activities. Methods: In this study, the effect of Bacillus pumilus (BP), Bacillus sp. (BSP) and the mixture (BPSP) was tested on the growth and the activity of digestive enzymes of the Rainbow trout. The autochthonous strains, previously characterized as potential probiotics in vitro, were administered individually at $1 \times 10^{7} \mathrm{CFU} \mathrm{g}^{-1}$ food and as a mixture, for the last one the concentration was $0.5 \times 10^{7} \mathrm{CFU} \mathrm{g}^{-1}$ of food for each one; during 8 weeks. Results: Neither of the strains used generated significant growth, compared to the control. Fishes fed with BSP had a better growth respect to BP and BPSP. The highest activity of enzymes was obtained in the fish treated with bacteria, but only BPSP-treated fish had a significant increase $(P<0.05)$ in the three enzymes activities, compared to the control. Under the current test conditions, individual strains had no significant effects on growth, but the consortium had a significant increasing effect on enzyme activities.
\end{abstract}

Keywords: Digestive enzymes; probiotics; Rainbow trout

\section{RESUMEN}

Antecedentes: Los probióticos en la acuicultura han ganado importancia, ya que pueden mejorar la salud de los peces debido a los efectos positivos en la fisiología digestiva de los animales y, consecuentemente, en el crecimiento. Objetivos: Evaluar el efecto de dos cepas bacterianas autóctonas con potencial probiótico sobre el crecimiento y la actividad de las proteasas totales, lipasa y amilasa de la trucha arcoíris. Métodos: Se evaluó el efecto de Bacillus pumilus (BP), Bacillus sp. (BSP) y la mezcla (BPSP) en el crecimiento y la actividad de enzimas digestivas de la trucha arcoíris. Las cepas autóctonas, previamente caracterizadas como potenciales probióticos in vitro, fueron suministradas a los peces a una densidad celular de $1 \times 10^{7} \mathrm{UFC}^{-1}$ de alimento, individualmente y la mezcla, a la mitad de la concentración cada una; durante ocho semanas. Resultados: Ninguna de las cepas empleadas generó crecimiento significativo, comparado con el control. Sin embargo, los peces alimentados con BSP tuvieron mejor crecimiento, respecto de BP y BPSP. La actividad enzimática (proteasas, lipasa y amilasa) más alta se obtuvo en los peces alimentados con BPSP, y fueron estadísticamente diferentes $(P<0.05)$ del control. Conclusiones: Las condiciones de experimentación evaluadas no generaron efecto significativo sobre el crecimiento y la actividad de las enzimas digestivas cuando las cepas se suministraron individualmente. El consorcio bacteriano incremento significativamente la actividad de los tres grupos enzimáticos de la trucha arcoíris.

Palabras clave: enzimas digestivas, probióticos, trucha arcoíris 


\section{INTRODUCTION}

The growing need for food at global and local level has led to the development of production methods adequately to supply the demand. Aquaculture plays an important role in this aspect and it is clear that, its role will be decisive in food production (FA0, 2016), in years to come. In Mexico, aquaculture production is a growing activity, and specifically the production of Rainbow trout has maintained a sustained growth in the last decades (García-Mondragón et al., 2013; SAGARPA, 2017). However, the production of this species begins to face associated complications related to improvement of health and nutrition of organisms in cultivation (FA0, 2018). Commercial diets for Rainbow trout don't offer any additional advantage other than the specified nutrient content, which doesn't guarantee their assimilation. This would mean food wastage, since it represents $40 \%$ to $70 \%$ of the total investment (Chao \& Liao, 2007). In this sense, fish digestion is based on the production and activity of endogenous enzymes (Alarcón et al., 1997; Ray et al., 2012), and, recently, it has been reported that thatits microbiota has an important role in fish digestion, because the bacterial community wide range of hydrolases to this process (Bairagi et al., 2002; Mondal et al., 2008). Lately, in aquaculture, the development and application of probiotics has gained importance, considering that they can exert beneficial effects on the host (Ray et al., 2012; Pandiyan et al., 2013). From the physiological point of view, positive relationships have been found between probiotics and the digestion process, particularly, on the production and activity of digestive enzymes (Yanbo \& Zirong, 2006; Rønnestad et al., 2013). Consequently, probiotics are an option to increasefish digestion leading to a better growth of organisms and, therefore, to aquaculture development (Zorriehzahraet al., 2016). This study aimed to determine the effect of Bacillus pumilus (BP), Bacillus $\mathrm{sp}$. (BSP), and a mixture of them (BPSP) on the growth and digestive enzymes activities of Oncorhynchus mykiss, focusing on improving the production in this species.

\section{MATERIAL AND METHODS}

Bacteria. Strains Bacillus pumilus and Bacillus sp., used in the present study, were isolated, identified, and characterized as potential probiotics under in vitro conditions by Ramírez-Torrez et al. (2018).

Fish and diet. The Rainbow trout fingerlings $(1.8 \pm 0.03 \mathrm{~g})$ were taken from the Aquaculture Center "El Zarco", Estado de México, Mexico, and transported to the Laboratorio de Producción Acuícola at FES IztacaIa-UNAM. Health condition, visible abnormalities, and absence of skin lesions or hemorrhage were corroborated on the fish. The organisms were aleatory selected and conditioned in a recirculation system for 15 days and fed with basal diet (Biofingerling of Malta Clayton $®$ ), following the feeding program indicated by the manufacturer. An average of 88 $\mathrm{g}$ of initial biomass was distributed in plastic tanks of $160 \mathrm{~L}$ each.The containers were distributed in aleatory blocks as well. Experimental groups remained independent of each other, and only same group replicates were in are circulating aquaculture system. The groups corresponded to one control (CTRL); and those treated with BP, BSP, or BPSP. For the CTRL, commercial food was provided without added bacteria. For the treatments, bacterias were added to the food at $1 \times 10^{7} \mathrm{CFU}$ $\mathrm{g}^{-1}$. Each strain of the consortium had a concentration of $0.5 \times 10^{7} \mathrm{CFU}$ $\mathrm{g}^{-1}$ of food. Bacteria were suspended in sterile distilled water, added to the food,mixing constantly, and aerated undera laminar flow hood for eight hours. Subsequently, the prepared food was stored according to manufacturer's recommendations. Twice a day, fishes were fed at $6 \%$ of their biomass, as recommended by the formulated food manufacturer. Administration of bacteria in food to the experimental groups was intercalated, i.e., in the first week no group received bacteria; in the second week, the bacteria (BP, BSP, or BPSP) were added to the treated groups, except to the CTRL, and so on successively until the eighth week.

Viability of bacteria added to the food. The bacteria's viability in the food was determined as follows: a sample of $5 \mathrm{~g}$ of prepared food was taken, suspended in sterile saline solution $(0.89 \%)$, adjusted to $10 \mathrm{~mL}$, and homogenized in a culture tube. An aliquot of $100 \mu \mathrm{L}$ was extracted, inoculated in $\mathrm{BH}$ agar plates. Viability was determined by counting the CFU per gram, after an incubation of $24 \mathrm{~h}$ at $30^{\circ} \mathrm{C}$; this was done on the first, fourth, and seventh day of having added the bacteria to the food (Madigan et al., 2012).

From the prepared food, bacteria was recovered as follows: a homogenate was prepared, three decimal sequential dilutions were made, and aliquots were inoculated in three culture media: BHI, MRS, and TCBS (Difco ${ }^{\mathrm{TM}}$ and BBL $^{\mathrm{TM}}$ Manual, NJ, USA). Agar plates were incubated at $32{ }^{\circ} \mathrm{C}$ for $24 \mathrm{~h}$. Each differentiated bacterial colony was subcultured onto culture plates and the isolated bacteria was identified by sequencing the gene encoding the 16S rRNA (Han, 2006; Mignard and Flandrois, 2006; Janda and Abbott, 2007), and amplified by the polymerase chain reaction (PCR), based onthe methodology described by Hamdan (2004) and Sambrook and Russel (2011).The DNA was isolated with the Wizard $®$ Genomic DNA Purification Kit (PROMEGA®, Madison, WI, USA). The PCR was performed with the Master Mix® PCR kit (PROME$\mathrm{GA}(\mathbb{B})$ with a total volume of $25 \mu \mathrm{L}$ of mixture reaction, according to manufacturer's instructions. In the thermocycler was induced (Bio-Rad $\mathbb{R}$ My Cycler, Hercules, CA, USA), following a pre-incubation cycle at $94^{\circ} \mathrm{C}$ for $5 \mathrm{~min} ; 40$ cycles of denaturation at $94^{\circ} \mathrm{C}$ for $38 \mathrm{~s}$, hybridization at $52^{\circ} \mathrm{C}$ for $40 \mathrm{~s}$, and pre extension at $72^{\circ} \mathrm{C}$ for $40 \mathrm{~s}$; followed by an extension cycle at $72^{\circ} \mathrm{C}$ for $7 \mathrm{~min}$ and, finally, a final cooling cycle at $4^{\circ} \mathrm{C}$. PCR amplicons were visualized on $1.5 \%$ agarose and stained with ethidium bromide $\left(0.5 \mu \mathrm{gmL}^{-1}\right)$, excited under $300 \mathrm{~nm}$. PCR products were purified with the Illustra $\AA$ Exoprostar $®$ kit $(G E \circledast$, CT, USA); sequencing was made by Macrogen, Inc. (Seoul, South Korea) and the information obtained was analyzed using the NCBI Blast algorithm and compared with the sequences available in the GenBank data base (https://www. ncbi.nlm.nih.gov/genbank/).

The strains used had more than $90 \%$ viability.

Growth determination. Assessment of fish growth was made by measuring its biomass at the beginning, and at four and eight weeks of experimentation, and determined as:

Weight gain (WG):

$$
W G=W_{f}-W_{i}
$$

Where:

$\mathrm{W}_{\mathrm{i}}$ : initial weight

$\mathrm{W}_{\mathrm{f}}$ : final weight

Relative growth (RG; Busacker et al., 1990): 


$$
\mathrm{RG}=\frac{\left(\mathrm{W}_{\mathrm{f}}-\mathrm{W}_{\mathrm{i}}\right)}{\mathrm{W}_{\mathrm{i}}} * 100
$$

Where:

$W_{i}$ : initial weight

$W_{f}$ : final weight

Specific growth rate (SGR; Ricker, 1979):

$$
\operatorname{SGR}=\frac{\left(\ln W_{\mathrm{f}}-\ln W_{\mathrm{i}}\right)}{\text { days }} * 100
$$

Where:

In $w_{i}$ : natural logarithm of initial weight

In $w_{\mathrm{f}}$ : natural logarithm of final weight

days: time of experimentation in days

Feed conversion ratio (FCR; Ramos et al., 2017):

$$
\mathrm{FCR}=\frac{\text { Food offered in grams }}{\text { weight gain }}
$$

Survival (S; Uribe \& Luna-Figueroa, 2003):

$$
S \%=\frac{\text { Final number of fish }}{\text { Initial number of fish }} * 100
$$

Digestive somatic index (DSl; Hidalgo et al., 1999):

$$
\text { DSI }=\left(\frac{\text { Weight of GIT }}{\text { Weight of fish }}\right) * 100
$$

Where:

\section{GIT: Gastrointestinal tract}

Enzyme activity determination. Fishes were fasted for 36 hours and, then, euthanized by thermal shock and subsequent decapitation (AVMA, 2013), and keptat $4^{\circ} \mathrm{C}$. The gastrointestinal tract (GIT) was removed and stored in an ultra-freezer (Thermo Fisher Scientific ${ }^{\circledR}$ Model: ULT1786-6-A49. Asheville, NC, USA), at $-70^{\circ} \mathrm{C}$, until the samples were processed. The GIT was homogenized at $2{ }^{\circ} \mathrm{C}$ and diluted $1: 9$ (weight: volume) in phosphate buffer ( $\mathrm{pH} 7.0)$. The suspension was centrifuged at 22,000 $g$ (Microfuge 22R, Beckman Coulter $\AA$, Brea, CA, USA), for 30 min at $4{ }^{\circ} \mathrm{C}$ and the supernatant was recovered. From this, aliquots of 100 and $200 \mu \mathrm{L}$ were prepared and stored at $-70^{\circ} \mathrm{C}$, until their analysis was made (AVMA, 2013; Cahu \& Zambonino-Infante, 1994).

The total protein content was measured, whit the Lowry method (Waterborg, 2002), done with the Total Protein Kit, Micro Lowry, Peterson's Modification with precipitation (Sigma-Aldrich, St. Louis, MI, USA), following the manufacturer's specifications. The assays were designed to obtain the specific activity from crude extracts of the fish GIT (Cahu \& Zambonino-Infante 1994; García-Ortega et al., 2003). To determine the specific activity of enzymes, a discontinuous spectrophotometric method was used (Nelson \& Cox, 2008; Bisen, 2014; Cornish-Bowden, 2014). The generation of the product in a given period was measured, expressed as the change of the mixture in optical density (OD) (Copeland, 2000; Mantle \& Harris, 2000).

Proteases. Total proteolytic activity was determined by the method of casein hydrolysis described by Kunitz (1947) and modified by Walter (1984). The total volume of the reaction was $1.2 \mathrm{~mL}$, composed of 250 $\mu \mathrm{L}$ of $1 \%$ casein $(\mathrm{w} / \mathrm{v})$ in sterile distilled water, $250 \mu \mathrm{L}$ of phosphate buffer, $\mathrm{pH} 7.0$, and $100 \mu \mathrm{L}$ of GIT extract; then incubated at $37^{\circ} \mathrm{C}$ for 1 h. The reaction was stopped by adding $8 \%$ trichloroacetic acid (Hidalgo et al., 1999; Furnéet al., 2005). The mixture was centrifuged at $1800 \mathrm{~g}$ for $10 \mathrm{~min}$ and $\mathrm{OD}$ was measured at $280 \mathrm{~nm}$. Tyrosine was used as a standard and one unit of proteolytic activity was defined as the amount of enzyme that releases $1 \mu \mathrm{mol}$ of tyrosine $\mathrm{mL}^{-1} \mathrm{~min}^{-1}$ (Furnéet al., 2005; Al-Saraji\& Nasir, 2013; Ahumada-Hernández et al., 2014).

Lipase. Specific activity of lipase was determined by titration of fatty acids released from the hydrolysis of an olive oil emulsion, $\mathrm{pH} 8.0$ (Näher, 1974; Ali et al., 2010). The mixture's total volume was $7.6 \mathrm{~mL}$, which consisted of $2 \mathrm{~mL}$ of olive oil emulsion (10\% of olive oil - $10 \%$ of acaciagum in distilled water), $0.4 \mathrm{~mL}$ of $0.6 \% \mathrm{CaCl}_{2}, 1 \mathrm{~mL}$ of phosphate buffer (pH 7.0), $0.2 \mathrm{~mL}$ of crude extract, and $4 \mathrm{~mL}$ of absolute alcohol-acetone (1:1) - phenolphthalein (0.09\%). The mixture was titrated with $0.1 \mathrm{~N} \mathrm{NaOH}$. A unit of specific activity was considered as the amount of enzyme that releases $1 \mathrm{mmol}$ of fatty acids in $1 \mathrm{~min}$ under specified conditions.

a-Amylase. Amylase activity was measured by the method described by Rick and Stegbauer (1974), based on starch hydrolysis, pH 7.0, detected from the release of the reducing group. The mixture'stotal volume was $1.2 \mathrm{~mL}$, composed of $50 \mu \mathrm{L}$ of starch solution $(0.5 \mathrm{~g}$ of soluble starch and $17.5 \mathrm{mg}$ of $\mathrm{NaCl}$ in $50 \mathrm{~mL}$ of $0.1 \mathrm{M}$ potassium phosphate at $\mathrm{pH} 7.0$ ), $50 \mu \mathrm{L}$ of crude extract, $100 \mu \mathrm{L}$ of dinitrosalicylate reagent (DNS, $1 \mathrm{~g}$ in $20 \mathrm{~mL}$ of $2 \mathrm{~N} \mathrm{NaOH}$ and $50 \mathrm{ml} \mathrm{H}_{2} \mathrm{O}, 30 \mathrm{~g}$ of K-Na tartrate and 100 $\mathrm{mL}$ distilled water), and $1 \mathrm{~mL}$ of distilled water. After adding the extract, the sample was incubated at $25^{\circ} \mathrm{C}$ for $5 \mathrm{~min}$ and after DNS addition, the mixture was incubated at $100{ }^{\circ} \mathrm{C}$ for $10 \mathrm{~min}$, then the $\mathrm{OD}$ was measured at $546 \mathrm{~nm}$. One unit was defined as the amount of enzyme that released $1 \mu \mathrm{mol}$ of reducing groups, calculated as maltose per minute from starch hydrolysis at $25^{\circ} \mathrm{C}, \mathrm{pH} 7.0$, and maltose as standard.

Data analysis. Biometrical data of fish and specific enzyme activities were tested for parametric statistical assumptions and one-way ANOVA was used to identify differences amongexperimental groups, considering bacterial strains as variation source. When ANOVA indicated significant differences $(\alpha<0.05)$, a Tukey test was applied to identify differences amonggroups (Montgomery, 2001; Zar, 2010). All analyses wereperformed with SYSTAT $®$ ver. 12 for Windows $®$.

\section{RESULTS}

Growth. There was no significant difference $(P>0.05)$ in the initial biomass amongthe experimental units. The animals grew more than $900 \%$ after 8weeks of experimentation; with a significant increase $(P<0.05)$ with respect to theirinitial weight. The survival rates among the groups didn't show significant differences. No significant effects $(P>0.05)$ or better growth were observed in the weight gain of the fish fed with bacteria compared to the CTRL during the eight weeks. However, when an ANOVA was made only amonggroupstreated with probiotics, the BSP group exhibited a better weight gain $(15.5 \pm 0.06)$ and was statistically different $(P<0.05)$, contrasted to BP $(14.7 \pm 0.06)$ and BPSP $(14.1 \pm$ $0.04)$. Nevertheless, no significant effects were detected in the remaining calculated parameters (Table 1).

Enzyme activity. The inclusion of bacterial strains had a positive effect on the activity of the digestive enzymes. The proteolytic activity after 8 
weeks of experimentation had a significant $(P<0.05)$ increase in fish fed with BPSP $(0.23886 \pm 0.000316)$, with the highest value, followed by BSP $(0.23816 \pm 0.001279)$, BP $(0.23099 \pm 0.000597)$, and CTRL $(0.22452 \pm 0.000492$; Fig. 1$)$. The lipase activity also displayed significant differences $(P<0.05)$ among groups and was higher in BSP $(0.68284 \pm 0.0001720)$ and BPSP $(0.69012 \pm 0.0004517)$, as compared to $\mathrm{BP}(0.68284 \pm 0.0001720)$ and $\mathrm{CTRL}(0.68277 \pm 0.0001394$; Fig. 2). The amylolytic activity was higher and statistically different $(P<$ $0.05)$ in BPSP $(0.03877 \pm 0.00000)$ than BS $(0.03801 \pm 0.00001)$, BP $(0.03803 \pm 0.00005)$, and CTRL $(0.03803 \pm 0.00002$; Fig. 3$)$. The strains mixture treatment showed the highest enzymatic activity produced in each case.

\section{DISCUSSION}

It has been reported that Bacillus strains have a positive effect on fish growth (Austin, 2006; Gómez \& Balcázar, 2008); however, they are more effective in early stages of development, probably because of the absence of a microbiota established in the GIT of the fish. On the other hand, positive results on growth have been obtained only after treating the fish with an antibiotic (Merrifield et al; 2010). In the same way, Park et al. (2017) reported that a 15-g Rainbow trout didn't show significant differences in growth. Also, it has been reported that Epinepheluscoioides (Hamilton, 1822) does not undergo a significant increase in weight gain and specific growth rate when fed with $B$. pumilus and $B$. clausii (Sun et al., 2010). In general terms, results obtained in this study agree with these authors. The density of bacteria inclusion in the food should also be considered, as Al-Saraji and Nasir (2013) reported that $1 \times$ $10^{5} \mathrm{CFU} \mathrm{g}^{-1}$ or $1 \times 10^{6} \mathrm{CFU} \mathrm{g}^{-1}$ increased significantly the growth of the common carp. However, the feeding habits of this fish should be considered, specifically when $B$. pumilus was used at $1 \times 10^{8}$ or $1 \times 10^{9}$ CFU g ${ }^{-1}$ of food, resulting in a significant weight gain (Srisapoome \&

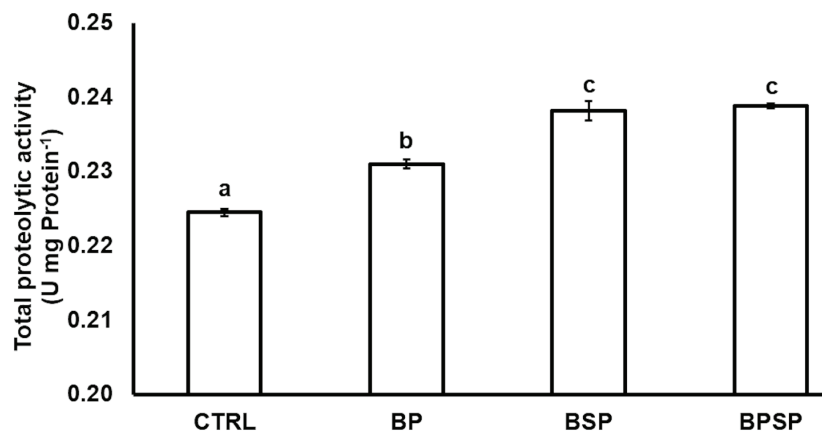

Figure 1.Total proteolytic activity of the gastrointestinal tract of Rainbow trout fed with autochthonous probiotics. Each column represents the means of three replicates \pm standard error. Different letters indicate significant difference between the means $(P<0.05)$.

Areechon, 2015). Probably, B. pumilus, as heterotrophic bacteria (Liu et al., 2013) exert more positive effects on fish with omnivorous feeding habits, such as Tilapia, compared to Rainbow trout, a carnivorous fish. Results indicate that there was no improvement in fish growth; however, treated fish had a homogeneous growth, which is important for aquaculture (Gisbert et al., 2014). Data point out the importance of experimentation, because from it we cank now the strain and its optimal density to obtain significant results for a specific host.

The use of probiotics in aquaculture has shown important advantages, because it can improve the digestion of fish, either by providing enzymes or stimulating secretion and, consequently, favoring the growth of organisms (Zorriehzahra et al., 2016). Bacillus species can produce a wide range of enzymes that can contribute to fish digestion (Bairagi et al., 2002); however, B. pumilus has been used most

Table 1. Growth performance of rainbow trout fed with different autochthonous probiotics. The values are the means of three replicates \pm standard error. Means with different letters in the same line differ significantly $(P<0.05)$.

\begin{tabular}{lcccc}
\hline & CTRL & BP & BSP & BPSP \\
\hline Fish weight & $1.8-17.9$ & $1.8-16.5$ & $1.8-17.3$ & $1.7-15.8$ \\
Ini $^{1}-$ Fin $^{2}(\mathrm{~g})$ & & & & \\
Change (\%) & 994 & 917 & 961 & 878 \\
WG $^{3}(\mathrm{~g})$ & $16.1 \pm 0.8^{\mathrm{a}}$ & $14.7 \pm 0.06^{\mathrm{b}}$ & $15.5 \pm 0.06^{\mathrm{a}}$ & $14.1 \pm 0.04^{\mathrm{b}}$ \\
$\mathrm{RG}^{4}(\%)$ & $878.5 \pm 10.01$ & $825.2 \pm 4.81$ & $862.4 \pm 3.88$ & $800.8 \pm 1.52$ \\
$\mathrm{SGR}^{5}(\% /$ day) & $4.06 \pm 0.01$ & $3.97 \pm 0.009$ & $4.04 \pm 0.007$ & $3.92 \pm 0.003$ \\
$\mathrm{FCR}^{6}$ & $2.1 \pm 0.1$ & $2.4 \pm 0.1$ & $2.2 \pm 0.1$ & $2.5 \pm 0.04$ \\
DSI $^{7}(\%)$ & $15.03 \pm 1.17$ & $17.7 \pm 0.97$ & $19.25 \pm 1.07$ & $18.68 \pm 0.54$ \\
Survival (\%) & $99.16 \pm 0.8$ & $95.83 \pm 1.7$ & $96.6 \pm 0.8$ & $96.6 \pm 0.8$ \\
\hline
\end{tabular}

IIni: initial

2Fin: final

${ }^{3}$ Weight gain

${ }^{4}$ Relative growth

${ }^{5}$ Specific growth rate

${ }^{6} \mathrm{Feed}$ conversion rate

${ }^{7}$ Digestive somatic index 
frequently to prevent and control diseases in White shrimp (Hilet al., 2009), E.coioides (Yang et al., 2014), and Nile Tilapia (Oreochromis niloticus L., 1758) (Srisapoome \& Areechon, 2017), but not as a probiotic to improve digestion or growth. Monospecific probiotics have not always produced best results; in herbivorous carp, $B$. subtilis Ch9 did not generate benefits in enzymatic activity, during a prolonged supply (Wu et al., 2012). B. pumilus did not improve E.coioides growth, but improved the immune system response (Sun et al., 2009). On the other hand, a mixture of Bacillus spp. produced the highest activity of proteases, lipases, and amylases in common carp (Yanbo \& Zirong, 2006). Nevertheless, contrary and according to Ozório et al. (2016), a bacterial consortium (B. subtilis, Enterococcus faecium, Pediococcus acidilactici, and Lactobacillus reuteri) didn't improve the growth of Rainbow trout, although anti-oxidative enzymes were lower in the treated group, but not significant against control. The results of the present study indicate that BPSP generated higher enzymatic activity, but not better growth.

Most published works have found a direct relationship between growth and activity of digestive enzymes in fish and crustaceans (Ziaei-Nejad et al., 2006; Zokaeifa et al., 2012; Hauville et al., 2016), in contrast to the results in this study in which the treatment with the mixture of strains did not show higher growth, although it produced higher enzymatic activity. When Fenneropenaeus indicus was fed with a consortium of Bacillus spp., digestive enzymes had greater activity and higher weight gain (Ziaei-Nejad et al., 2006). In Rainbow trout fingerlings an opposite behavior was observed because fish fed with $B$. cereus var. toyoi grew better than the control, but there was no significant effect on digestive enzymes activity (Gisbert et al., 2014). Another study showed that the use of Bacillus sp. didn't improve digestive enzymes activity or increase the growth of fish (Koca et al., 2015), in agreement with this study.

There are aspects related to probiotics that should be considered: strain and density, time and frequency of administration and fish developmental stage. Also, whether testing was made under laboratory or in culture conditions (Welker \& Lim, 2011; Cha et al., 2013). The ability of $B$. pumilus to control a bacterial infection in Nile Tilapia has been evaluated and, at $1 \times 10^{6} \mathrm{CFU}$, fish didn't develop the infection (Aly et al., 2016). In another study, a density of $1 \times 10^{8} \mathrm{CFU}$ of $B$. pumilus didn't show any significant effect on $E$. coioides growth, but there was a significant difference with B. clausii, at the same density (Sun et al., 2010). $B$. pumilus was assessed at $1 \times 10^{10} \mathrm{CFU}$ and produced best survival rate, but not better growth, when fishes were challenged with Streptococcus iniae; it was $B$. subtilisthat significantly increased these two parameters (Cha et al., 2013). B. pumilus has been tested to prevent or control diseases, rather than growth (Avella et al., 2010). Its action has even been identified on genes expression associated with the immune system in the intestinal mucosa of E. coioides (Yang et al., 2014). This was also reported in Rainbow trout with Enterococcus faecium (Panigrahi et al., 201) and L. plantarum (Pérez-Sánchez et al., 2011). In some cases, density values were higher than those used in this study and produced significant effects, and in other cases, these values were lower. This provides information about the importance of this variable and of the time of evaluation of bacterial strains with probiotic potential, that is, the relationship between the observed effects and cell densities.

It's important to consider the experimental time and the frequency of bacterial supplementation in this study. Published works evaluated growth on a daily probiotic supply (Adineh et al., 2013; Buruiană et al.,

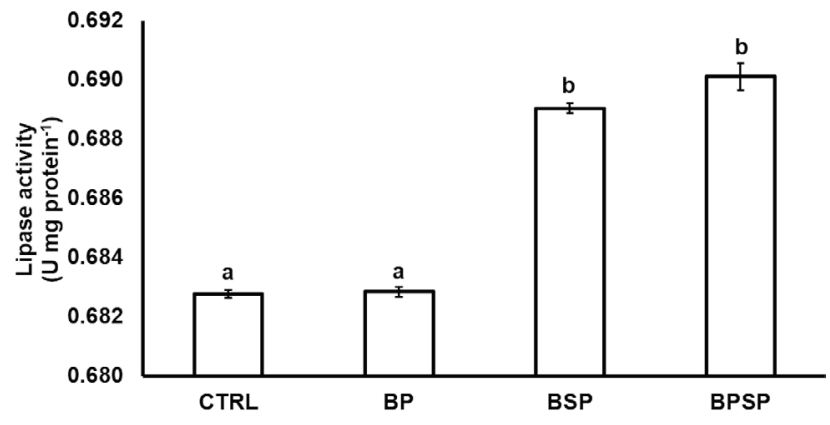

Figure 2.Lipase activity of the gastrointestinal tract of Rainbow trout fed with autochthonous probiotics. Each column represents the means of three replicates \pm standard error. Different letters indicate significant difference between the means $(P<0.05)$.

2014; Chen et al., 2016), mainly through bacteria added to food, only not many added to water (Hauville et al., 2016). In some cases, feeding was done at libitum (Giannenas et al., 2015) and in others feeding rate was calculated from fish biomass. In the present study, strains supplementation was intercalated during the eight weeks. It means that on the first week no bacteria were added to food of any experimental group; on the second week, strains were added to experimental groups, but not to the CTRL and so on until the eighth week. Therefore, a comparison between two methods, continuous and discontinuous probiotic administration, is necessary, because a beneficial effect was observed. The experimental time was eight weeks, a period in which growth changes of rainbow trout can be observed (FA0, 2018; Woynarovich et al., 2011),based that the investigation initial proposal was evaluate two strains in a specific phase growth.

In contrast with other studies, which didn't obtain significant effects after 99 days of $B$. amyloliquefaciens supply (Reda \& Selim, 2015); in another study, significant growth was obtained in fish after 30 culture days, but not up to 60 (Sun et al., 2010). In this sense, most published works tested the strains of interest in relatively short periods, from 30 to 60 days (Giannenas et al., 2015; Afrilasari et al., 2016; Adeoye et al., 2016), and in some cases only for a week (Hauville et al., 2016), eva-

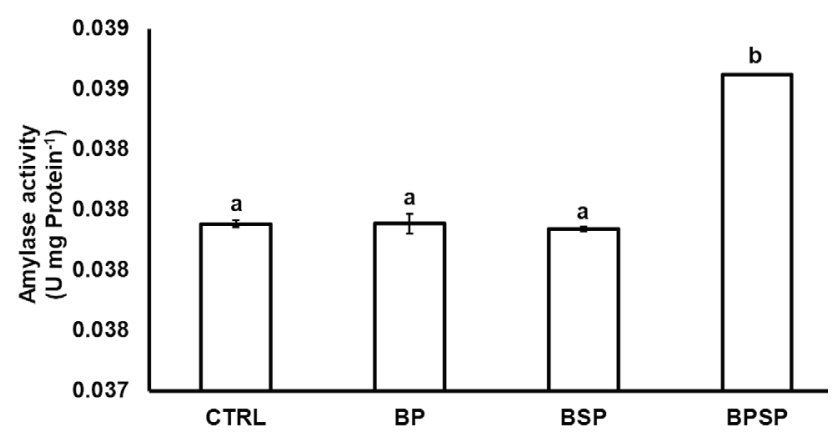

Figure 3.Amylase activity of the gastrointestinal tract of Rainbow trout fed with autochthonous probiotics. Each column represents the means of three replicates \pm standard error. Different letters indicate significant difference between the means $(P<0.05)$. 
luating only the larval phases. Therefore, results depend mainly on the growth stage in which the bacterial strain is to be evaluated.

From a physiological point of view, significant growth effects on fish and crustaceans have been reported (Bidhan et al., 2014) regarding the bacterial enzymes contribution to the host (Bidhan et al., 2014; Allameh et al., 2017). No mechanism has been proposed to explain this relationship (Welker \& Lim, 2011). Growth is an event in which many variables are involved, because not all the energy assimilated from the diet is used exclusively for growth; therefore, the digestive enzymes activity isn't necessarily related to it (Lucas \& Southgagte, 2012). The fish biomass is not the only way to estimate growth (Wootton, 2011), considering that energy demand exists even in the absence of growth (Nelson, 2011). In this sense, it is necessary to assess other enzymes that are linked with fish metabolism. Not many studies have made this proposal. For example, some studies evaluated glycolytic and oxidative enzymes activity in wild Atlantic cod (Gadusmorhua L.) and obtained a strong positive relationship between these and growth (Pelletier et al., 1995). In addition, they associated protein and DNA content in muscle with previously mentioned enzymes activity.

\section{CONCLUSIONS}

The probiotics and cellular density used didn't improve fish growth, resulting in a similar fish growth in all experimental treatments; this finding can be useful for aquaculture, because it could generate homogeneous lots. Bacterial mixture had a positive and significant effect on digestive enzymes activity. In this study, autochthonous bacteria of Rainbow trouts were used not under laboratory settings, but in a study conducted under culture conditions, which provides essential information on probiotic functionality, their development, and implementation.

\section{ACKNOWLEDGEMENTS}

The first author is grateful to the Consejo Nacional de Ciencia y Tecnología (CONACYT) for the scholarship provided. The authors kindly acknowledge funding support by the Universidad Autónoma Metropolitana - Xochimilco, for the Functional Foods for Aquatic Organisms project, number: 34307016, and Programa de Apoyo a Proyectos de Investigación e Innovación Tecnológica (PAPIIT) of DGAPA-UNAM, project number IN213115.

\section{REFERENCES}

Adeoye A. A., R. Yomla, A. Jaramillo-Torres, A. Rodiles, D. L. Merrifield \& S. J. DAvies. 2016. Combined effects of exogenous enzymes and probiotic on Nile tilapia (Oreochromis niloticus) growth, intestinal morphology and microbiome. Aquaculture. 463: 61-70.

Adineh H., H. Jafaryan, J. Sahandi \& M. Alizadeh. 2013. Effect of Bacillusspp. Probiotic on growth and feeding performance of rainbow trout (Oncorhynchus mykiss) larvae. Bulgarian Journal of Veterinary Medicine 16: 29-36.

Afrilasari W., Widanarni \& A. MeryandinI. 2016. Effect of probiotic BaciIlus megaterium PTB 1.4 on the population of intestinal microflora, digestive enzyme activity and the growth of catfish (Clarias sp.). HAYATI Journal of Biosciences23: 168-172.

Ahumada-Hernández R. I., C. A. Alvarez-González, R. Guerrero-Zarate, R. Martínez-García, S. Camarillo-Coop, A. Sánchez-Zamora, M. G. Gaxiola-Cortes, I. G. Palomino-Albarrán. D. Tovar-Ramírez \& E. Gisbert. 2014. Changes of digestive enzyme activity on yellowtail snaper (Ocyuruschrysurus) during initial ontogeny. International Journal of Biology 6(4): 110-117.

Alarcón F. J., M. Diaz \& F.J. Moyano. 1997. Studies on digestive enzymes in fish. Characterization and practical applications. Cahiers Options Mediterranées22: 113-122.

ALI S., H. RAFI \& IKRAM-UL-HAQ. 2010. Production of an extracellular lipase from Candida lipolytica and parameter significance analysis by Plackett-Burman design. Engineering in Life Science 10(5): 465473.

Allameh S. K., V. Noaman \& R. Nahavandi. 2017. Effect of probiotic bacteria on fish performance. Advanced Techniques in Clinical Microbiology 1: $1-2$.

Al-sara. A. Y. J. \& N. A. N. Nasir. 2013. Effect of different dietary proteins in the common carp fingerlings (CyrprinuoscarpioL.) reared in floating cages. Mesopotamian Journal of Marine Science 28(2): 121-130.

Aly S. M., A. M. Abd-El-Rahman, G. John \& M. F. Mohamed. 2008. Characterization of some bacteria isolated from Oreochromis niloticus and their potential use as probiotics. Aquaculture 277: 1-6.

American Veterinary Medical Association (AVMA). 2013. Guidelines for the Euthanasia of Animals: 2013. Available online at: https://www. avma.org/KB/Policies/Documents/euthanasia.pdf (downloaded august 2016)

Austin B. 2006. The bacterial microflora of fish, revised. The Scientific World Journal 6:931-945.

Avella M. A., G. Gioacchini, 0. Decamp, P. Makridis, C. Bracciatell \& 0. CarNEVALI. 2010. Application of multi-species of Bacillus in sea bream larviculture. Aquaculture 305: 12-19.

Bairagl A., K.S. Ghosh, S. K. Sen \& A. K. Ray. 2002. Enzyme producing bacterial flora isolated from fish digestive tracts. Aquaculture International 10(2): 109-121.

Bidhan C. D., D. K. Meena, B. K. Behera, P. Das, P. K. Mohapatra \& A. P. Sharma. 2014. Probiotics in fish and shellfish culture: immunomodulatory and ecophysiological responses. Fish Physiology and Biochemistry 40: $921-971$.

Bisen P. S. 2014. Enzymology. In: Bisen P. S. (Ed.). Laboratory Protocols in Applied Sciences. CRC Press, pp. 547-617.

Buruiană C.-T., A. G. Profir \& C. Vizireanu. 2014. Effects of probiotic baciIlus species in aquaculture - an overview. The Annals of the University Dunarea de Jos of Galati Fascicle VI - Food Technology 38: 9-17. 
Busacker P. G., R. I. Adelman \& M. E. Goolush. 1990. Growth. In: Schreck B. C. \& B. P. Moyle (Eds.). Methods for Fish Biology. American Fisheries Series, pp. 363-387.

Cahu C. L. \& J. L. Zambonino-Infante. 1994. Early weaning of sea bass (Dicentrarchuslabrax) larvae with a compound diet: effect on digestive enzymes. Comparative Biochemistry and Physiology Part A: Physiology 109(2): 213-222.

Cha J.-H., S. RahimneJad, S.-Y. Yang, K.-W. Kim \& K.-J. Lee. 2013. Evaluation of Bacillus spp. as dietary additives on growth performance, innate immunity and disease resistance of Olive Flounder (Paralichtysolivaceus) against Streptococcus iniae as water additive. Aquaculture 402-403: 50-57.

Chen Y., J. LI, P. XIAO, G. Y. LI, S. Yue, J. Huang, W. Y. Zhu \& Z. L. Mo. 2016. Isolation and characterization of Bacillus spp. M001 for potential application in turbot (Scophthalmus maximus L.) against Vibrio anguillarum. Aquaculture Nutrition 22: 374-381.

Copeland R. A. 2000. Experimental measures of enzyme activity. In: Copeland R. A. (Ed.). Enzymes, Wiley-VCH, pp. 188-265.

Cornish-Bowden A. 2014. Analysis and interpretation of enzyme kinetic data. Perspectives in Science 1(1-6): 121-125.

FA0. 2016. The state of world fisheries and aquaculture. Contributing to food security and nutrition for all. Available at: http://www.fao. org/3/i9540en/19540EN.pdf (downloaded December 2017)

FA0. Programa de información de especies acuáticas. Oncorhynchus mykiss. Programa de información de especies acuáticas. 2018. Available from: [http://www.fao.org/fishery/culturedspecies/0ncorhynchus_mykiss/es]. Accessed: January 14, 2018).

Furné M., M. C. Hidalgo, A. López, M. García-Gallego, A. E. Morales, A. DomezalN, J. DomezalnÉ \& A. Sanz. 2005. Digestive enzyme activities in Adriatic sturgeon Acipensernaccarii and rainbow trout Oncorhynchus mykiss. A comparative study. Aquaculture 250: 391-398.

García-Mondragón, D., I. Gallego-Alarcón, A. Espinoza-Ortega, A. García-Martínez \& C. M. ArRiAgA-JoRdÁn. 2013. Desarrollo de la producción de trucha arcoíris (Oncorhynchus mykiss) en el Centro de México. Revista AquaTIC 38: 46-56.

García-Ortega A., J. Verreth \& H. Segner. Post-prandial protease activity in the digestive tract of African catfish Clariasgariepinus larvae fed decapsulated cysts of Artemia. Fish Physiology and Biochemistry 22: $237-244$.

Giannenas I., I. Karamaligas, M. Margaroni, I. Pappas, E. Mayer, P. Encarnação \& E. KARAGOUNI. 2015. Effect of dietary incorporation of a multi-strain probiotic on growth performance and health status in rainbow trout (Oncorhynchus mykiss). Fish Physiology and Biochemistry 41: 119-128.

Gisbert E., M. Castlllo, A. Skalli, K. B. Andree \& I. Badiola. 2014. Bacillus cereus var. toyoi promotes growth, affects the histological organization and microbiota of the intestinal mucosa in rainbow trout fingerlings. Journal of Animal Science 91: 2766-2774.

Gómez G. D. \& J. L. BalcázAr. 2008. A review on the interactions between gut microbiota and innate immunity of fish. FEMS Immunology \& Medical Micicrobiology 52: 145-154.
HAN X. Y. 2006. Bacterial Identification Based on 16S Ribosomal RNA gene sequence analysis. In: Yi-Wei Tang \&W. Charles W. Stratton (Ed.). Advanced techniques in diagnostic microbiology. New York, Springer, pp. 323-332.

Hamdan P. 2004. Biomonitoreo: seguimiento de poblaciones microbianas en procesos de biorremediación de suelos contaminados con hidrocarburos. Ms thesis in Biotechnology.Mexico, Universidad Autónoma Metropolitana- Iztapalapa.

Hauville M.R., J. L. Zambonino-Infante, J.G. Bell, H. Migaud \& K. L. Main. 2016. Effects of a mix of Bacillus sp. as a potential probiotic Florida pompano, common snook and red drum larvae performances and digestive enzyme activities. Aquaculture Nutrition 22: 51-60.

Hidalgo M. C., E. Urea \& A. Sanz. 1999. Comparative study of digestive enzymes in fish with different nutritional habits. Proteolytic and amylase activities. Aquaculture 170: 267-283.

Hill J. E., J. F. C. Baiano \& A. C. Barnes. 2009. Isolation of a novel strain of Bacillus pumilus from penaeid shrimp that is inhibitory against marine pathogens. Journal of Fish Diseases 32: 1007-1016.

JANDA J. M. \& S. L. ABBotT. 2007. 16S rRNA gene sequencing for bacterial identification in the diagnostic laboratory: pluses, perils, and pitfalls. Journal of Clinical Microbiology 45: 2761-2764.

Koca S. B., N. Ö. Yigit, B. I. Didinen, S. Metin, H. Bayrak, E. E. Onuk, I. İ lian, H. ERAlp \& Í. Diler. 2015. Effects of enzyme-producing probiotic bacteria isolated from the gastrointestinal tract of trout on the growth performance, survival, and digestive enzyme activity of rainbow trout fry (Oncorhynchus mykiss). The Israeli Journal of Aquaculture -Bamidgeh IJA_67.2015.1190.

KunItz M. 1947. Crystalline soybean trypsin inhibitor: Il. General properties. The Journal of General Physiology 30: 291-310.

LIAO I. C. \& N. H. CHAO. 2007. Taiwanese aquaculture at the crossroads. In: Leung P. S., C.-S. Lee \& P. J. O'Bryen (eds.) Species and Systems Selection for Sustainable Aquaculture. Oceanic Institute, Hawaii, pp. 161-174.

Liu Y., Q. Lal, C. Dong, F. Sun, L. Wang, L. Guangyu \& Z. Shao. 2013. Phylogenetic diversity of the Bacillus pumilus group and the marine ecotype revealed by multilocus sequence analysis. PLOS ONE 8(11): e80097. doi:10.1371/journal.pone.0080097

LuCAS J. S. \& P. C. SouthGagte. 2012. Reproduction, Life Cycles and Growth. In: Lucas J. S. \& P. C. Southgate (Ed.). Aquaculture farming aquatic animals and plants, 2d edition. Wiley- Blackwell, pp. 126-137.

Madigan M. T., Martinko J. M., Stahl D. A. \& Clark D. P. 2012. Viable counts. In: Brock biology of microorganisms, 13th edition. New York Benjamin Cummings, pp. 129-131.

MantLe T. J. \& D. A. HarRIs. 2000. Spectrophotometric assays. In: Michael G. Gore, (Ed). Spectrophotometry and Spectrofluorimetry: a Practical Approach. Oxford University Press, pp.183-208.

Merrifield D. L., A. Dimitroglou, G. Bradley, R. T. M. Baker \& J. Davies. 2010. Probiotics applications for rainbow trout (Oncorhynchus mykissWalbaum) I. Effects on growth performance, food utilization, intestinal microbiota and related health criteria. Aquaculture Nutrition 16: 504-510. 
MignaRd S. \& J.P.FLANDRoIs 2006. 16S rRNA sequencing in routine bacterial identification: A 30-month experiment. Journal of Microbiological Methods 67: 574-581.

Mondal S., T. Roy, S. K. Sen \& A. K. Ray. 2008. Distribution of enzyme-producing bacteria in the digestive tracts of some freshwater fish. Acta Ichthyologica et Piscatoria 38(1): 1-8.

Montgomery D. C. 2001. Design and analysis of experiments, 5th edition. John Wiley and Sons Inc.

NäHER G. 1974. Lipase - tritimetric assay. In: Bergmeyer H. U. (Ed.). Methods of enzymatic analysis, $2 d$ edition. Academic Press, pp. 814818.

Nelson D. L. \& M. M. Cox. 2008. Enzymes. In: Nelson D. L. \& M. M. Cox (Eds.). Lehninger Principles of Biochemistry, 5th edition. Freeman and Company, pp. 183-227.

Nelson J. A. 2011. Energetics: an introduction. In: Farell A. P. (Ed.). Encyclopedia of fish physiology: from genome to environment, Vol 3. Academic Press-Elsevier, pp. 1563-1566.

Ozório R. 0. A., J. Kopecka-Pilarczyk, M. J. Peixoto, R. Lochmann, R. J. Santos, G. Santos, B. Weber, J. Calheiros, L. Ferraz-Arruda, P. Vaz-Pires \& J. F. M. GonÇALVES. 2016. Dietary probiotic supplementation in juvenile rainbow trout (Oncorhynchus mykiss) reared under cageculture production: effects on growth, fish welfare, flesh quality and intestinal microbiota. Aquaculture Research 47: 2732-2747.

Pandiyan P., D. Balaraman, R. Thirunavukkarasu, G. E. E. Jothi, K. SubaramaNiYan, S. ManiKkam \& D. Sadayappan. 2013. Probiotics in aquaculture. Drug Invention Today 5(5): 55-59.

Panigrahi A., V. Kirona, S. Satoh, I. Hirono, T. Kobayashi, H. Sugita, J. Puangkaew \& T. Aokı. 2007. Immune modulation and expression of cytokine genes in rainbow trout Oncorhynchus mykiss upon probiotic feeding. Developmental \& Comparative Immunology 31: 372-382.

Park Y., S. Lee, J. Hong, D. Kim, M. Moniruzzaman \& S. C. Bal. 2017. Use of probiotics to enhance growth, stimulate immunity and confer disease resistance to Aeromonas salmonicida in rainbow trout (Oncorhynchus mykiss). Aquaculture Research 48: 2672-2682.

Pelletier D., U. B. Pierre, J.-D. Dutil \& H. Guderley. 1995. How should enzyme activities be used in fish growth studies? Journal of Experimental Biology 198: 1493-1497.

Pérez-Sánchez T., J. L. Balcázar, D. L. Merrifield, 0. Carnevali, G. Gioacchini, I. DE Blas \& I. Ruiz-Zarzuela. 2011. Expression of immune-related genes in rainbow trout (Oncorhynchus mykiss) induced by probiotic bacteria during Lactococcus garvieae infection. Fish \& Shellfish Immunology 31: 196-201.

Ramirez-Torrez J. A., M. del C. Monroy-Dosta, L. H. Hernández-Hernández, J. Castro-Mejía, J. A. Bustos-Martinez \& A. Hamdan-Partida. 2018. Presumptive probiotic isolated from Oncorhynchus mykiss (Walbaum, 1792), cultivated in Mexico. International Journal of Aquatic Science 9(1): 3-12.

Ramos M. A., J. F. M. Gonçalves, B. Costas, S. Batista, R. Lochmann, M. A. Pires, P. Rema \& R. 0. A. Ozorio. 2017. Commercial Bacillus probiotic supplementation of rainbow trout (Oncorhynchys mykiss) and brown trout (Salmo trutta): growth, immune responses and intestinal morphology. Aquaculture Research 48(5): 2538-2549.

Ray A. K., K. S. Gosh, E. RingØ. 2012. Enzyme-producing bacteria isolated from fish gut: a review. Aquaculture Nutrition 8 (5): 465-492.

REDA R. M. \& K. M. SELIM. 2015. Evaluation of Bacillus amyloliquefaciens on the growth performance, intestinal morphology, hematology and body composition of Nile tilapia, Oreochromis niloticus. Aquaculture Interantional 23: 203-217.

Rick W. \& H. P. Stegbauer. 1974. a - Amylase. Measurement of reducing groups. In: Bergmeyer H. U. (ed.). Methods of enzymatic analysis, 2d edition. Academic Press, Inc., pp. 884-889.

RiCKeR W. 1979. Growth rates and models. In: Hoar W. \& D. R. J. Brett (eds). Fish Physiology. vol. 3, Bioenergetics and Growth. Academic Press, pp. 677-743.

Rønnestad I., M. Yúfera, B. Ueberschär, L. Ribeiro, Ø. Seele \& C. Boglione. 2013. Feeding behaviour and digestive physiology in larval fish: current knowledge, and gaps and bottlenecks in research. Reviews in Aquaculture 5(Suppl. 1): S59-S98.

SAmbrook J. y Russel D. W. 2011. In vitroamplification of DNA by the polymerase chain reaction, In:Joseph Sambrook and David W. Russel (eds.), Molecular cloning, A laboratory manual, vol. 2, $3^{\text {rd }}$ ed. New York. 8.1-8.126.

Secretaría de Agricultura, Ganadería, Desarrollo Rural, Pesca y Alimentación (SAGARPA). 2017. Avanza México como una potencia en producción acuícola Ciudad de México, April 15, 2017. Comunicado de Prensa. La Paz Baja California Sur; Available from: [http://www. sagarpa.gob.mx/Delegaciones/bajacaliforniasur/boletines/2017/ abril/Documents/2017BS135.PDF].

Srisapoome P. \& N. Areechon. 2017. Efficacy of viable Bacillus pumilus isolated from farmed fish on immune responses and increased disease resistance in Nile tilapia (Oreochromis niloticus): Laboratory and on-farm trials. Fish and Shellfish Immunology 67:199-210.

Sun Y.-Z., H.-L. Yang, R.-L. MA \& W.-Y. Lin. 2010. Probiotic applications of two dominant gut Bacillus strains with antagonistic activity improved the growth performance and immune responses of grouper Epinepheluscoioides. Fish and Shellfish Immunolology 29: 803809.

Uribe A. E. \& J. Luna-Figueroa. 2003. Efecto de dietas con diferente contenido proteico en las tasas de crecimiento de crías de bagre del Balsas Ictalurus balsanus (Pisces: Ictaluridae) en condiciones de cautiverio. Revista Aquatic 18: 39-47.

Walter H. E. 1984. Proteinases: method with hemoglobin, casein and azocoll as substrate. In: Bergmeyer H. U. (Ed.). Methods of Enzymatic Analysis, vol. 5. Verlag Chemie, Weinheim, pp. 270-277.

Waterborg J. H. 2002. The Lowry Method for Protein Quantitation. In: J. M.Walker (ed.). The Protein Protocols Handbook, 2d edition. Humana Press, pp. 7-9.

WeLkER T. L. \& C. LIM. 2011. Use of probiotics in diets of Tilapia. Journal of Aquaculture Research and Development S1: 014 
Wootton R. J. 2011. Energetics of Growth. In: Farell A. P. (ed.). Encyclopedia of fish physiology: from genome to environment, Vol 3. Academic Press-Elsevier, pp. 1623-1628.

Woynarovich A., G. Hoitsy \& T. Moth-Poulsen. 2011. Small-scale rainbow trout farming. FAO Fisheries and Aquaculture Technical Paper No. 561. $81 \mathrm{pp}$. Available online at: http://www.fao.org/docrep/015/ i2125e/i2125e.pdf (downloaded August 29, 2017)

Wu Z. X., X. Feng, L. L. XIE, X. Y. Peng, J. Yuan \& X. Chen. 2012. Effect of probiotic Bacillus subtilis Ch9 for grass carp, Ctenopharyngodonidella (Valenciennes, 1844), on growth performance, digestive enzyme activities and intestinal microflora. Journal of Applied Ichthyology 28: $721-727$.

YanBo W. \& X. Zirong. 2006. Effect of probiotics for common carp (Cyprinus carpio) based on growth performance and digestive enzyme activities. Animal Feed Science and Technology 127(3-4): 283-292.

YANG H.-L., H.-Q. XIA, Y.-D. YE, W.-C. Zou \& Y.-Z. Sun. 2014. Probiotic Bacillus pumilus SE5 shapes the intestinal microbiota and mucosal immunity in grouper Epinepheluscoioides. Diseases of Aquatic Organisms 111: 119-127.

ZaR J. H. 2010. Biostatistical Analysis, 5th edition. New Jersey: Prentice Hall, $947 \mathrm{p}$.

Ziael-Nejad S., M. H. Rezael, G. A. Takami, D. L. Lovett, A. R. Mirvaghefi \& M. Shakouri. 2006. The effect of Bacillus spp. bacteria used as probiotics on digestive enzyme activity, survival and growth in the Indian white shrimp Fenneropenaeus indicus. Aquaculture 252: 516-524.

Zokaeifa H., J. L. Balcázar, S. C. Roos, K. M. Salleh, K. Sijam, A. Arshad \& N. NeJAT. 2012. Effects of Bacillus subtilis on the growth performance, digestive enzymes, immune gene expression and disease resistance of white shrimp, Litopenaeus vannamei. Fish \& Shellfish Immunology 33: 683-689.

Zorriehzahra M. J., D. S. Torabi, M. Adel, R. Tiwarl, K. Karthik, K. Dhama \& C. C. LAZADO. 2016. Probiotics as beneficial microbes in aquaculture: an update on their multiple modes of action: a review. Veterinary Quarterly 36(4): 228-241. 